\title{
Citizen Surveillance of the State: A Mirror for eGovernment?
}

\author{
Jeroen Verplanke ${ }^{1}$, Javier Martinez ${ }^{1}$, Gianluca Miscione ${ }^{1}$, Yola Georgiadou ${ }^{1}$, \\ David Coleman ${ }^{2}$, and Abdishakur Awil Hassan ${ }^{1}$ \\ ${ }^{1}$ University of Twente, Faculty of Geo-information Science and Earth Observation - ITC, \\ P.O. Box 6, 7500AA Enschede, The Netherlands \\ ${ }^{2}$ University of New Brunswick, Canada \\ verplanke@itc.nl, martinez@itc.nl, miscione@itc.nl, \\ georgiadoulitc.nl, dcoleman@unb.ca, hassan22386@itc.nl
}

\begin{abstract}
This paper discusses, conceptually and empirically, the role of geographic ICT (geoICT) and virtual globes (e.g. Google Earth) at the interface of public policy and citizens. Our preliminary findings from on-going field work in an Indian city and in Zanzibar suggest that virtual globe technology can potentially transfer to citizens surveillance power, traditionally held by the government. Starting from the traditional electronic government framework, where bureaucracy acts as a filter between policy makers and citizens with grievances, we outline an emerging framework where commercial virtual globes act as mediators between policy-makers and citizens. We show that the emerging framework holds the potential of allowing citizens concerned, in our case, about the quality of water services, to influence policy makers directly. The virtual globe acts as a mirror to the traditional eGovernment framework and lends a different societal visibility both to public services provision, and to localized citizens' needs.
\end{abstract}

Keywords: Geographic ICT (geoICT), Electronic Government (eGovernment), Electronic Grievance (eGrievance), Virtual Globe, Google Earth (GE), Volunteered Geographic Information (VGI).

\section{Introduction}

Electronic government (eGovernment) research has focused mainly on individual government organizations and on the impacts of information and communication technology (ICT) on the capabilities of single government units [1]. Zouridis and Thaens [2] argue that the four spheres of traditional government-policy, politics, organization, citizens - have been affected only partly by ICT.

Table 1 summarizes the spheres of government and the rather limited loci of eGovernment. In the policy sphere, eGovernment concentrates mainly on policy implementation, not on agenda setting and policy development. In politics, ICT's role is mainly in democratic supervision (online access to laws and regulations). In public sector organizations, ICT plays a role only at the operational core of public administration, 
Table 1. Locus of traditional government and of eGovernment, adapted from Zouridis and Thaens [2]

\begin{tabular}{|c|c|c|}
\hline Spheres & Traditional Government & $\begin{array}{l}\text { Electronic } \\
\text { Government }\end{array}$ \\
\hline Policy & $\begin{array}{l}\text { Problem acknowledgement and agenda setting, } \\
\text { policy development and decision making, } \\
\text { policy implementation, policy control }\end{array}$ & Policy implementation \\
\hline Politics & $\begin{array}{l}\text { Representation, idea generation and consideration, decision } \\
\text { making and deliberation in parliament, democratic } \\
\text { supervision }\end{array}$ & $\begin{array}{l}\text { Democratic } \\
\text { supervision }\end{array}$ \\
\hline $\begin{array}{l}\text { (Public) } \\
\text { Organization }\end{array}$ & $\begin{array}{l}\text { Executives; Strategic top; Operating Core; Technostructure; } \\
\text { Support Staff }\end{array}$ & Operating core \\
\hline Citizens & $\begin{array}{l}\text { Citizens as rulers (voters \& participants in policy processes); } \\
\text { Citizens as ruled (subject to authority, consumers of services) }\end{array}$ & $\begin{array}{l}\text { Citizens as consumers } \\
\text { of services }\end{array}$ \\
\hline
\end{tabular}

due to the emphasis on service delivery. In the citizens' sphere, eGovernment is mostly concerned with citizens as passive consumers of services.

eGovernment has been studied mainly in the North. In the South, research on this topic is scarce, and the situation of such efforts is uncertain. Heeks [3] estimates that eGovernment projects are 35\% total failures, 50\% partial failures and $15 \%$ successes. He attributes failure to the gap between hard rational design and soft political realities caused by the three-way association of IT, universalist modernization and Western rationalism. His argument resembles Avgerou's [68], who claims that different rationalities coexisting within and around ICT projects are a major issue for their understanding, and development.

Despite their narrow focus and the limited success to date, eGovernment initiatives around the world still aim to transform all spheres of government, especially the interface between different stages of the policy cycle-problem acknowledgement and agenda setting, policy development and decision making, policy implementation, policy control—and citizens. In problem acknowledgement and agenda setting, significant visibility gains may accrue to citizens and policy makers alike if they can collectively "visualize" places identified as problem areas-places signaled and tagged by citizens' grievance reports or places where complaints are acknowledged. Locating and visualizing these places requires geographic ICT (geoICT) to be integrated to the eGovernment system.

Since the launch in June 2005 of Google Earth (GE), commercial virtual globes have been hailed for providing the "benefits of accessibility, interactivity, and engagement in landscape visualisation to millions, with the promise of greater representativeness in the views seen by users, improved accuracy of 3D imagery, and accelerated learning" [42, p. 14]. Citizens stand a realistic chance to influence policy \& decision making, not because of intended government action, but due to unintended consequences [71] of action taken by global market actors, driven by advertising revenue and market share. Are these developments inverting the panoptic power of the state and vesting surveillance power to citizens? What are the social and political implications? Due to the novelty of virtual globes, empirical research, especially in the South, is practically non-existent.

Here, we discuss the extent to which virtual globes can expand the limited focus of eGovernment, based on preliminary findings and insights from our own research in 
two empirical cases; in an Indian city and on Zanzibar. We focus on the potential role of geoICT and virtual globes in improving citizen participation in problem acknowledgement and agenda setting.

\section{2 eGrievance Systems, Virtual Globes and Volunteered Geographic Information (VGI)}

eGovernment initiatives in industrialized and developing countries hold the promise of a more citizen-centric government with reduced operational costs [4]. Governments use ICT to deliver efficient and cost effective services, information and knowledge [5]. Some authors claim that the adoption of a private sector management model, emphasizing the accountability of managers and a results orientation, will transform the public sector [6]. With online public services, especially through the internet, increasingly seen as part of a broader service (improvement) strategy, citizen dissatisfaction with the quality of the services may quickly become a major political issue $[7,8]$. Although the telephone and face-to-face contact are still more frequently used, and are rated higher than internet contacts [9], many studies reveal the increasing use of the internet for service provision to citizens $[10,11]$, as well as improved citizens' interaction with government $[12,13]$.

Citizens usually contact local government to request a service or information, lodge a complaint or voice their opinions, among other reasons. The contacts tend to be "geared toward matters of everyday service delivery rather than large-scale policy" [22]. Good contact experiences are important to both citizens and governments. The government may learn about the concerns of its citizens, their "contents and discontents." Citizens may learn of government services and benefits, how government functions, who is responsible for certain decisions. A satisfactory contact experience may improve a citizen's feeling of trust towards their government [20].

Other values hailed as constituting "good governance", such as participation, transparency, responsiveness, equity and inclusiveness, effectiveness, efficiency, and accountability may also be upheld in government-citizen contacts $[23,10]$.

Specifically, one of the ways ICT is expected to change the relationship between citizens and local governments is by facilitating participation. Citizen participation in local governance is significant in two respects: citizen participation reveals their collective preferences, ensures that local government is responsive to their needs, strengthens representative institutions and enhances democratic legitimacy [14, 15]. Out of the two main streams identified for eGovernment adoption-the supply side (government to citizen) and the demand side (citizen to government)—only the supply side is well documented in the literature $[16,17,18,19]$. The demand side of eGovernment adoption is less explored [20, 21].

\section{1 eGrievance Systems}

Grievance (redressal) systems are a particular type of citizen-initiated contact within eGovernment [24, 25]. Other terms, including complaint handling mechanisms [26], citizens' complaints [27, 28, 26] and public feedback mechanisms [29] are regarded as synonymous to, and interchangeable with, grievance systems. Grievances can be 
defined as "an expression of dissatisfaction [...] about [...] action or lack of action or about the standard of a service", as suggested by the British Local government Ombudsman [30].

Seneviratne and Cracknell [31] summarized four characteristics of clearly defined procedures of complaint handling in local governments: "bottom up" accountability of the grievance system, rational decision making of local governments, non-exit options for citizens unlike business consumers, and the political nature of liberal democracies, positing legitimacy and accountability as the ultimate test of successful government transformation.

Several local governments, both in the North and in the South ${ }^{1}$, have adopted electronic versions of complaint handling, in other words electronic Grievance (eGrievance) systems. In India, citizens register their complaints via the internet or use SMS over their mobile phone for urgent complaints [32]. Generally, eGrievance systems are viewed positively [25], in particular their potential to increase openness and transparency within the public administration [32]. Another example is the public service monitoring system in Tanzania, on Zanzibar, supported by UN-Habitat [33]. Here a system depending entirely on mobile communications technology has been set up as a pilot to monitor public water services. The system promotes transparency by visualizing citizens' complaints regarding water quality and availability directly through a web-client on a dedicated website using Google Maps.

It is because of these abilities that eGrievance systems are considered the key to increase transparency in e-Government initiatives [29]. The level of complaints can be expressed in a range of indicators - including measures of citizen satisfaction, accuracy, quality and reliability of services - that together indicate whether citizens are getting the service that they need and want [34]. This is well documented in environmental complaints where the complaint is seen as the perception of existing environmental problems $[35,36,25]$. This distinction is fundamental: the systems being discussed here are not intended to monitor the actual status of service delivery, but citizens' needs and the distance between expectations and provision.

Brewer [26] argues that "accountability may be weakened when service recipients are defined less in terms of their citizenship and more on the basis of a narrowly defined status as a marketplace consumer." When citizens are framed as electronic consumers, government may be more responsive only to certain groups in society [37], citizens with an electronic link to government, thus weakening overall government accountability. The inherent "responsiveness bias" in traditional government-citizen contacts, which Schumaker and Getter [38] defined as "the degree to which governments respond unequally to the preferences of various subpopulations in their communities", may become a "digital divide" between categories of people and the differences between people who are connected and people who are not connected [39].

Complaint handling, or service recovery, is central to customer service operations. Complaints comprise an important form of data and show firms where service quality falls below the standards of customer expectations [40]. Does responsiveness to complaints (or complainers) constitute better service to the public? And when public

\footnotetext{
${ }^{1}$ With "North and South" we refer in this document to the traditional division between the industrialized countries in the Northern hemisphere and the lesser developed countries that are mostly situated in the Southern hemisphere.
} 
servants are encouraged to "listen to the customer," what arrangements will ensure that they listen to those customers less able to exercise their voice, who cannot or do not express their preferences well or clearly, and who may receive poorer quality service if greater discretion is given to frontline personnel? And are there ways in which a customer service focus ignores-or worse, exacerbates-inequalities among customers? The above mentioned questions pose critical aspects of electronic grievance systems that could exacerbate the inequality of citizens if not managed properly. Theoretically, what is in question here is the rationalization function that the bureaucracy is supposed to exercise on society. Bureaucracy is intended to transform political problems into administrative problems by applying formal procedures equally for all. Is it going in that direction?

\subsection{Virtual Globes and Volunteered Geographic Information (VGI)}

The emergence of commercial virtual globes and the advent of web 2.0 open new possibilities for citizens to interact with other citizens and government. Web 2.0 allows collaboration in which users are able to interact with each other, to provide information to central sites, and to see that information is collated and made available to others [41]. Combining Web 2.0 functionalities with virtual globes, such as Google Earth, is meaningful for issues where place and spatial information are at the forefront, either for citizens or service providers. Web 2.0 combined with Google Earth allows earlier participation and multiple views in planning processes, possibilities for online feedback and dialogue, multiple views of the world expressed simultaneously, especially in environmental issues [42]. It also offers NGOs the ability to do technical analyses, causing shifts in the epistemic balance of power between civil society and the state as a result [43].

While Google Earth is foremost a commercial internet application, driven by marketing share and advertising revenue, people use it to explore the world, to look for well documented anomalies [44], derive pleasure from searching for black helicopters, engage in virtual tourism and creatively make subversive mash-ups [45]. Volunteers produce, use and 'produse' [69] geographic information in social networking and collaborative web-based efforts like Open Street Map, Tagzania, Wayfaring.com, the People's Map, and Platial: The People's Atlas. Volunteered geographic information (VGI) provided by citizens redistributes the rights to define and judge the value of the geographic information and of a new production system in general [65].

On the other hand, creativity and active sites of resistance (counter-mapping) to military secrecy by a conscious re-purposing of mapping and satellite imagery have consequences. Counter-mapping practices show how panoptical power can be reclaimed by those formerly cast as subject to the gaze of the state [45]. This in turn leads to concerns of legitimacy. Visualizations and graphics created by lay people may be seen as less dangerous, because they carry less authority. However, when such 'unofficial' graphics find their way into the public discourse or decision-making, they can raise difficult issues for society, such as "who has a legitimate voice?", "whose visualization is right, or more legitimate?" [42]. Kingsbury and Jones [44] and Parks [46] provide examples from Google Earth to illustrate different versions of "truth" or emphasis on "urgency to act" for example with regard to thematic coverage of the crisis in Darfur. Spatial-temporal discrepancies between added media and 
underlying maps and images can (willingly or not) create a picture that appears more realistic than it actually is.

Trust issues are for instance raised about the absence of metadata [47] for geographic information supplied through Google Earth (and most other virtual globes) regarding the commercial actors controlling the data, its quality and accessibility. International organizations and citizens are dependent on (a limited number of) third party commercial wares to share geographic information in a user friendly fashion. Google is quite willing to exercise control over data access that has never been freely communicated. In trusting commercial companies, we may be running the risk of developing public delusion over what is happening in the world [48], since image currency and resolution reflect perceptions of market potential and not of public interest [49]. Also scientific information is shared through virtual globes and 'cloud based' collaboration software. Concerns over control and access to scientific information in turn can raise questions about the credibility of science similar to the way these questions are asked with regard to third-party financing of research. Pursuing it blindly risks entering into a Faustian bargain expedited with privatized corporate data, which may place scientific endeavors under great restrictions, and, in the end, may replace scientific fact with corporate and government fictions and undermine the creditability of science [49].

\subsection{Reflection}

eGovernment was spurned by the need to regain public trust in government. Much of the effort however has gone into electronically connecting different parts of government to improve efficiency and effectiveness (G2G). To reclaim public trust eGovernment provides services to citizens $(\mathrm{G} 2 \mathrm{C})$ and the business (private) sector $(\mathrm{G} 2 \mathrm{~B})$ (see table 2). Schematically, eGovernment $=\mathrm{G} 2 \mathrm{G}+\mathrm{G} 2 \mathrm{C}+\mathrm{G} 2 \mathrm{~B}$.

In principle, eGovernment is also offering citizens an opportunity (platform) to voice their issues and complaints (grievances). Feedback mechanisms from both the public and private sector fall under eGrievance systems, which we represent schematically as eGrievance $=\mathrm{G} 2 \mathrm{C}+\mathrm{G} 2 \mathrm{~B}$. eGrievance systems enable societal actors to voice their concerns. Some of them were designed years ago from a top-down perspective, therefore we label them G2C. More recent ones, adopting Web 2.0 approach and tools, can be labelled $\mathrm{C} 2 \mathrm{G}$ because the initiative comes from users; we introduce an example later. Citizens are in general responsive to questions that governments ask about policies or societal issues. eGrievance also facilitates feedback mechanisms that redress complaints on the malfunctioning of a pre-defined set of services.

On the other hand, when citizens seize initiative and confront government with issues, it is not commonly done through e-channels. Social networks and mass media play a role in collecting grievances and pooling them. Particularly, the media play an important role in raising public attention to grievances. Media visibility is essential for grievances to reach government. But currently more and more social issues are pooled through electronic social networks and brought to the attention of international agencies. Interest groups and (multinational) NGOs are also using these same social networks to push or pull at the relevant issues for their own agenda setting. 
Table 2. Key features of information flows, adapted from Craglia et al. [47]

\begin{tabular}{|c|c|c|c|c|}
\hline & Lead Actors & Key Drivers & $\begin{array}{l}\text { Main Target } \\
\text { Audience }\end{array}$ & $\begin{array}{l}\text { Implementation } \\
\text { mechanism }\end{array}$ \\
\hline eGovernment & Public sector & Public trust & $\begin{array}{l}\text { Citizens + private } \\
\text { sector }\end{array}$ & Services to citizens \\
\hline Virtual globes & Private sector & $\begin{array}{l}\text { Market share \& } \\
\text { Advertising } \\
\text { Revenue }\end{array}$ & Mass market & $\begin{array}{l}\text { Market + } \\
\text { voluntary }\end{array}$ \\
\hline VGI & Citizens & Social networking & Citizens & Voluntary \\
\hline
\end{tabular}

\section{Surveillance Power from the State to the Citizens?}

Traditionally, bureaucracy has the role of bridging the gap between the formal political sphere and citizens. Its main legitimation lays in the aim of rationalizing society by channelling social relations in formal procedures that are based on formal rationality rather than value rationality. Ideally, it guarantees equal and universal access to public administration and downplays the role of tradition and charismatic figures. Weber (in "The Protestant Sects and the Spirit of Capitalism" 1920) expresses his concerns about the bureaucratization of society with his famous metaphor of the "iron cage". The last century showed that such a modernization path is not necessary, as different rationalities continue to exist and proliferate, Foucault being an exemplar author on this line.

Indeed, the universal institutionalization of formal rationality is not likely to happen any time soon. Information systems such as those being discussed here -based on perceived needs and wants that may sideline bureaucracy- do not seem to bring us towards an iron cage. Rather, mutual visibility and continuous negotiation appear as the way ahead for citizens and decision makers. Hoogenboom and Ossewaarde [70] argue that such a relation between state and citizens was legitimized by a 'legalrational authority' which cannot be taken for granted in 'late modernity', characterized by different and competing rationalities. Late modernity sees the rise of reflexive organizations that are more dependent on their actual environments. "Reflexive organizations further democratization because they force a bureaucratic elite to take the personal and social needs of the lay people seriously and they force them to communicate openly" [70]. On the other hand, these kind of organizations risk being less universalistic, and more affected by individual qualities. With this framework in mind, we will introduce two examples of eGovernment efforts that are in line with the idea of reflexive authority.

Citizen empowerment through eGovernment would entail the inversion of the grievance system (eGrievance $\left.{ }^{-1}\right)$. Such a bottom up approach depends on citizens or the private sector taking initiative and finding a platform to confront government with their grievance (eGrievance $\left.{ }^{-1}=\mathrm{C} 2 \mathrm{G}+\mathrm{B} 2 \mathrm{G}\right)$. Few examples exist of such inverted systems and there are several consequences to take into account if such a system is to work.

Traditional eGovernment and eGrievance structures in particular can be represented with a classic top down scheme where information travels down and up between policy makers and citizens through the bureaucratic filter of public administration (figure 1). With the constitution of a more visible and vocal citizenship, 
where information exchange between citizens is growing increasingly through accessible and easy to use applications, the individuality of citizen grievance can be pooled through platforms by themes and preferably also location. International agencies set these themes as well, concerning wide issues ranging from water and sanitation, to women's emancipation and health. On the one hand International agencies follow MDG's to set their agendas, on the other hand they can follow citizen inputs [58].

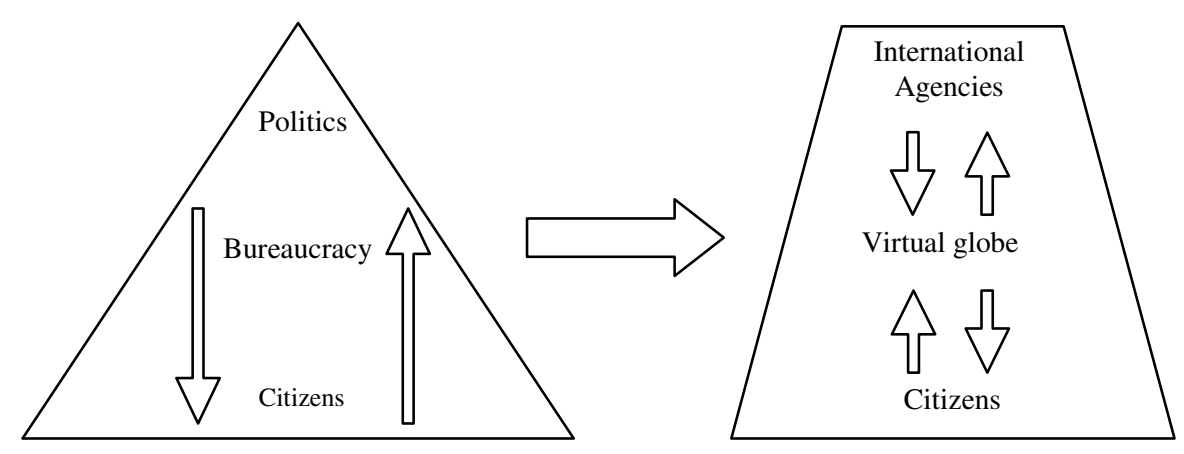

Fig. 1. An emerging setting for eGovernment, from traditional to a setting with geoICT acting as an intermediary

This emerging setting fits well with the concept of eParticipation. eParticipation uses ICT as a utility to get citizens more involved in improving the public service, public administration and social cohesion. More and more links are made between governments and citizen communities. Poelmans and Van der Linde [50] differentiate three forms of eParticipation:

1. Political participation. How to involve citizens in the decision-making process?

2. Policy participation. Citizens and governments cooperate together at the implementation and maintenance of policy.

3. Social participation. How to reinforce the mutual involvement of citizens?

On the traditional (left) side of figure 1 these three forms of participation are dependent on the bureaucratic ability to govern information flows. Particularly social participation depends on the agility and transparency of that bureaucracy. If the bureaucracy is not equipped to captivate citizens, eParticipation will lose its momentum and its effect. Even if bureaucracy is functioning optimally it can act as a filter to both sides of the system. Probably not a deliberate filter, but the eGovernment system is not equipped to organize all citizen demands into policy input, nor can it give enough transparency to policy objectives.

Moving to eParticipation with a wider perspective, citizen interests and international agendas become interdependent drivers for political and social participation. The relative ease of providing location information with complaints through embedded GPS devices offers interesting opportunities for organising information spatially through virtual globes. Virtual globes are places where citizens and the private sector 
gather to provide and acquire geo-located knowledge, experiences and information about services. The specific nature of information provided on virtual globes is the spatial information attached to all available data. Combining data sources provides possibilities for discovering business opportunities or enabling the identification of hotspots [51, 52] for all sorts of purposes.

Visualization of localized themes of grievances could provide citizens and policymakers with a different view into objectives and demands.

\subsection{An eGrievance System in India}

The implementation of the eGrievance system in Kalyan-Dombivili (India) was triggered and framed under the pro-poor policies and reforms in urban areas required by the Jawaharlal Nehru National Urban Renewal Mission Programme (JNNURM), which mandates the implementation of ICT and eGovernment tools. In KalyanDombivili this is listed in the approved City Development Plan as the "introduction of a system of e-governance" [53]. One of the components is a module called "Complaints and Redressal System". The program was initiated by the Kalyan Dombivili Municipal Corporation (KDMC) in 1999 and implemented in 2002 [54]. The objective was to create "a system driven by Municipal Corporation with highest levels of transparency, accountability and citizen servicing standards." The benefits claimed for the citizens were: time bound service delivery, transparency and accountability in the corporation's functioning; hassle free interactions with quicker response time for all the services; objectivity in decision making, leading to more impartial and transparent governance.

Both the public and private sector participate in the development and implementation of the programme. This includes the Indian Institute of Technology, National Centre for Science and Technology and TATA Institute of Fundamental Research, VJTI (engineering college in Mumbai) and Mumbai based ABM Knowledgeware Ltd [54].

Citizens can formally submit grievances through a complaint handling mechanism that offers several access points. The procedure can be initiated via the Internet, via the phone but also via a group of public offices called "citizen facilitation centres" (CFCs). An analysis of the mode of delivery of the complaints in 2007 showed that more than $90 \%$ of all complaints in KDMC are delivered by hand, only $6 \%$ are submitted online and a negligible proportion by phone [25]. The eGrievance system allows the formal filing of complaints and captures from bottom-up the grievances of the citizens. However, when it comes to specifying the sort of grievance, the citizen is limited to a top-down pre-defined list of possible categories or to the interpretation of the phone operator who finally codifies the complaint. The eGrievance system is designed to direct the complaint to the department responsible for the solution of the complaint. In principle citizens are able to trace the complaint.

Some typical categories in the eGrievance refer to needs that -if not satisfied- might affect the quality-of-life of the most deprived (e.g. no water supply) but others just reflect the "wants" and discontent of some citizens (the better off, as data shows) with what they perceive as urban blight (e.g. encroachments, slums, hawkers, beggars). Research on the composition and spatial distribution of complaints showed that the eGrievance system favors citizen participation only of a particular citizen group, the 
middle class [25]. A visual comparison of maps showing the concentration of complaints and the different levels of multiple deprivation (Figure 2) indicates that the complaints do not necessarily concentrate in the most deprived areas. These maps were also shown to city officials, politicians and self-help groups from poorer areas. From this it was also found that no one felt that the concentration of complaints accurately reflected the areas in the city with the greatest need for water and drainage improvements.

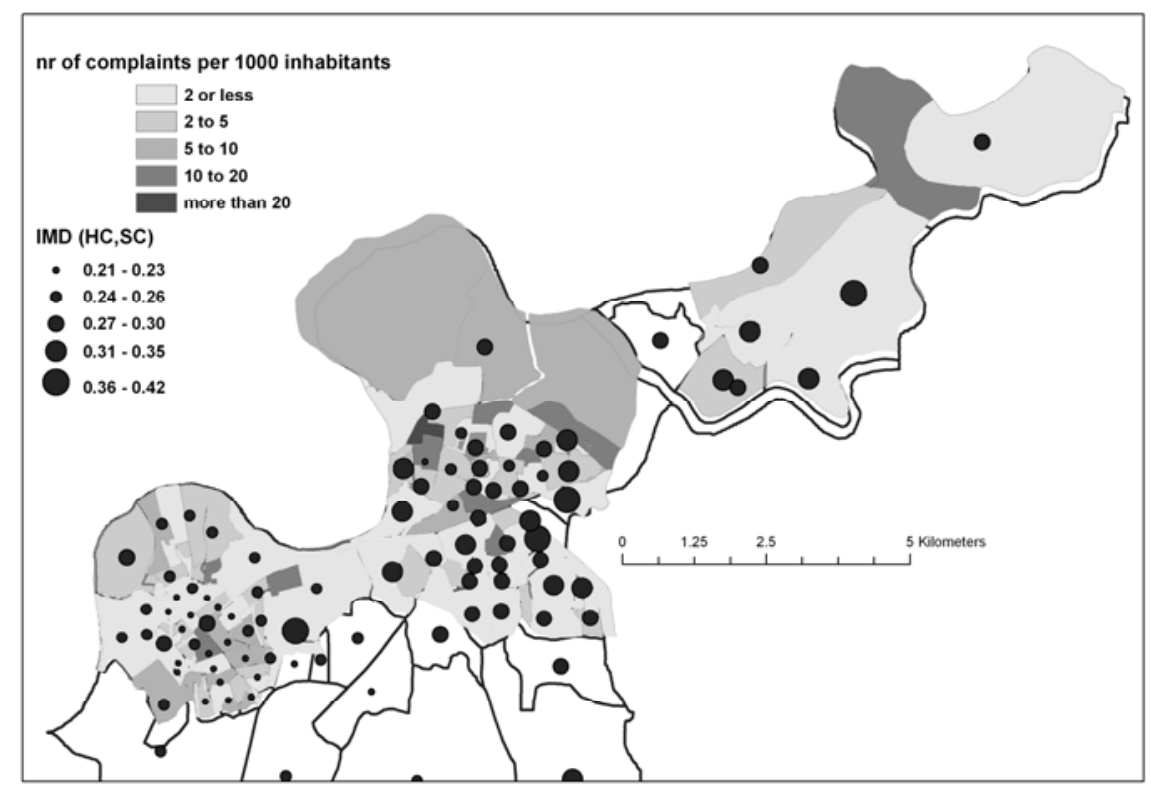

Fig. 2. Overlay of complaints (grays) and Index of Multiple Deprivation (IMD) (symbols). Note: High values in IMD indicate a high multiple deprivation index [25].

The system is biased towards the middle class agenda. In terms of its capacity for "problem acknowledgement and agenda setting" the system captures the wants (of the better-off) rather than the needs of all the citizens and in particular those who are worst-off.

Some of the usual potentials of eGovernment are being claimed for KDMC's eGrievance system. Despite receiving several awards and being replicated in other municipalities, an analysis of local newspapers reinforce the limitations. The system does not necessarily speed up the resolution of complaints. Some people still prefer to have face-to-face interaction when placing a complaint or they are not aware of the existence of the system $[55,56]$.

\subsection{A Human Sensor Web in Zanzibar}

In Tanzania, UN-Habitat and Google.org, the philanthropic arm of Google.com, entered a partnership in 2009 aiming at improving water services offered by the Zanzibar Water Authority. The project aims at improving access to information on 
water coverage, assessing the level of satisfaction by citizens and evaluating efficiency in the delivery of services by the water authority. The complaint handling mechanism and platform is still in the research phase, being administered by different researchers [57], but is operational to the extent that local actors can manage the system. The only external facilitator envisioned for the system is Google, which provides the technical infrastructure and hosts the web-based system.

The initiative, at its initial prototyping and testing stages, is experimenting with the use of mobile phone networks to report deficiencies in water supply and to track efficiency in maintenance response through a web-based information system. It is a novel approach in which citizen generated information is provided to decision and policy makers (possibly in a focused, timely, and effective manner). Information received from cell phones is stored on servers and linked to a virtual globe for public visualization on the internet. The novelty is the accountability possibly achieved through publicly available, aggregated information on the status of, and relative performance in, water services provision. The project aims to deliver essential information 'up the pipe' directly from consumer to provider and decision maker through the use of standard mobile devices, and 'down the pipe' to the consumer and to society in the form of community groups, political representatives and the media [33].

The Human Sensor Web (HSW) is a combination of a community of individuals who report observations through existing, widespread mobile communication technology and a set of (web) services that provide means to disseminate observations made by the community and means to receive feedback from individuals, specific user groups and civil society. Citizens use their mobile phones to report about a malfunction. These reports are received by the (public) service provider and simultaneously visualized in a virtual globe environment. Not only the service provider responsible for fixing the malfunction can see these reports but all interested parties - citizens and the state - can access the spatial representation of grievances online and observe the quality of services (malfunctions and also speed of repair) [72].

Mobile phones are becoming the most widespread sensor device in the world offering the possibility of capturing voice, pictures, video and location data in combination with a versatile interface that connects to global communication networks. ${ }^{2}$ Goodchild [41] has proposed using "human sensors" and web2.0 to unlock the vast pool of local spatial knowledge as Volunteered Geographic Information (VGI). The emerging framework in figure 3 is particularly appealing for this idea. Virtual globes offer a wide variety of ways to include VGI as is shown by the Amazonian example from Google Earth Outreach [58]. Several other examples of eGrievance systems exist which could easily be used or adapted to use the concept of VGI in the emerging framework.

Success of the HSW depends to an extent on the accessibility of mobile telecommunications. The availability of the technology is an important issue [59] but accessibility, as in ownership of mobile phones, can also manifest itself as a shortcoming in

\footnotetext{
${ }^{2}$ Mobile phone users are mostly "equal" to the point that there is just a financial obstacle that denies its ownership or use. Phone ownership for instance can be limited to certain societal classes (wealthy businessmen) in its early adoption. In some societies however this is not so straight forward. Certainly in traditional societies in lesser developed countries there are cultural factors that govern the use and ownership of mobile phones.
} 


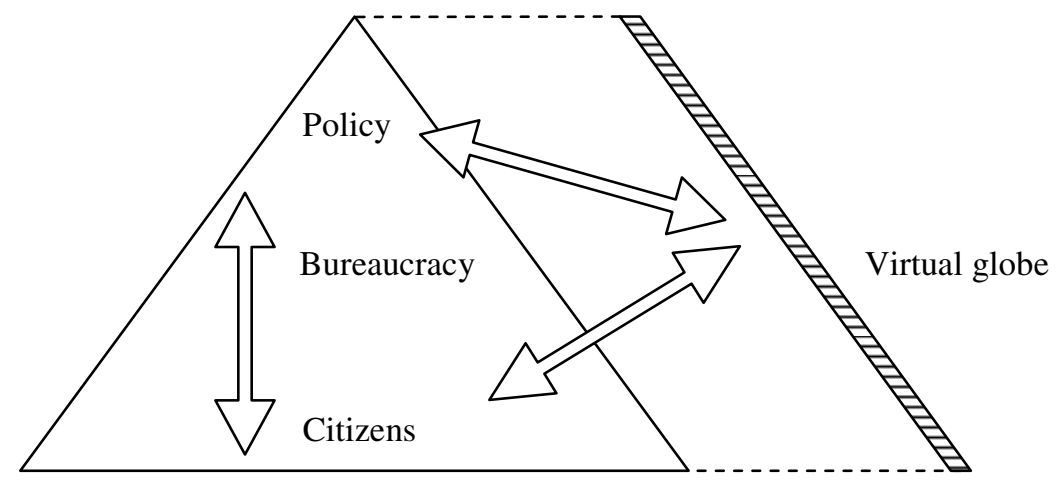

Fig. 3. Virtual globe as a mirror for citizen surveillance of the state

representation. According to Sung [60] gender issues play a role in this case on Zanzibar. In many rural areas it is men who have phones but women who have grievances to report because they are usually in charge of collecting water. This issue causes delays in responses and makes information transmitted by a third party less reliable. To what extent this HSW project therefore reflects wants, needs or rights and whether it also favours the middle class, or any specific part of society is not yet known.

\section{Discussion and Conclusions}

VGI can be dubbed "participatory sensing" given the nature of geo-data generation by dispersed volunteers, where the voluntary aspect and the personal interest and motivation to contribute information are central. The cases presented show how volunteered geographic information (VGI) can become a relevant aspect of an eGrievance ${ }^{-1}$ system [65]. VGI is usually generated to inform other citizens and is not by itself specifically purposeful. VGI can be none other than blogged references to great places to visit. But it might as well be geo-tagged pictures of illegal activities (deforestation, waste dumps etc.) directly submitted to authorities [58]. As argued by Craglia et al. [47], platforms like Google Maps and Google Earth are combining both voluntary and institutional data. Without a mechanism to clearly distinguish the different nature of the data (through metadata), it will be difficult for citizens to take action and for administrators and policy makers to make accountable decisions on the basis of such data. If citizens are to be engaged or involved more in government decisions by sharing their knowledge (data, information and understanding) it should be done in a manner that maintains accessibility but also improves reliability and backs trust. It is of course not only trust in the platform and whether that platform displays the "truth" [46]. Governance innovations are required for VGI to be put to good use and citizens must be trusted to provide the right information reciprocally.

Rather than going into the details of systems that are under continuous development, we stress how our cases aim at affecting service provision activities by managing stakeholders' mutual and external visibility differently. Indeed, the eGrievance systems and the early steps of the human sensor web that we presented show the 
emergence of a different framework for eGovernment (figure 1). With respect to eGrievance, the Human Sensor Web example (or eGrievance ${ }^{-1}$ ) positions the interactions it mediates and data hereby produced, outside of the conventional bureaucratic procedures that eGrievance systems are designed upon. With this the old idea of control [66] is possibly reverted, or becoming exploitable by the controlled.

By becoming a side addition to the existing tools like eGrievance, human sensed data on virtual globes act as a mirror through which policy-makers and citizens become more visible to each other. Accountability lines are therefore affected. Bureaucracy is likely to keep filtering citizen pressure, and the same citizens are likely to find workarounds to affect agenda setting. The virtual globe as a mirror (figure 3) acts on the well known mechanism of showing and blaming: facilitating the public visualization of public interest issues like service provision, they leverage public opinion in a less ad-hoc fashion than mass media. It is quite likely that corporations or groups of citizens will be able to exploit the virtual globe to "sell" their point of view or product to a potentially broader audience. On the other hand, citizens become more visible to the state. The mediating role of the private sector is expected to focus itself on the transparent development and management of such platforms.

The expansion to live satellite feeds in the near future for instance will have dramatic consequences for the identification, tracking and sorting of individuals. With CCTV the controlling power of surveillance is in few hands, while massive surveillance with live satellite feeds is available to everybody [62]. So, we sketch some concerns and possible risks related to development of VGI towards unintended uses of user generated data. This concept is mentioned by Lane et al. [63] who also describe "opportunistic sensing". Opportunistic means in this case not volunteered information but automated extraction from possibly the same sensors (mobile phones) as used for VGI. The earlier examples of Swine flu and traffic hotspots [51, 52, 64] are typical examples of opportunistic sensing but one can also continue this line of thinking to include Google's analysis of search engine data [67]. This type of sensing is bothersome as it does not require consent from the "sensor owner" to access or use the data. In the light of the control discussion this gives an important dimension to consider.

Nevertheless, when vested interests are at play, concerns over private corporations owning a virtual globe give reason to debate, even concern. Entrusting a mediating role between citizens and public authorities to the private sector opens important discussions about free speech and media. Potential for using a virtual globe to access and disseminate spatial information have been presented. On the other hand, virtual globes have become very popular, and more voices stress the disadvantages or risks of leaving them to commercial partners. Parks [46], Kingsbury and Jones [44] and Harvey [48] critically analyze the risks that corporate ownership of these platforms in most cases also means corporate ownership or copyright of the information disseminated through these platforms. These issues have been voiced earlier about the handling of spatial information in general [61].

So, what is happening to the 'iron cage' of formal rationality that Weber envisioned one century ago? By becoming more allowed to see the state, citizens may engage in negotiations with public administrations that may lead to more alertness and accountability, but also to unequal responsiveness from public administrations. In such a context, we see the possibility for "reflexive authority, which can be defined as the belief in the ability of institutions and actors to negotiate, reconcile and represent 
arguments, interests, identities and abilities." [70] For now, as it goes beyond the scope of this paper, we leave it open for discussion if state visibility mediated by geoICT goes more in the direction of the reflexive modernity proposed by Ulrich Beck and Anthony Giddens, or if it substantiates the postmodern paradigm.

Acknowledgement. The authors wish to recognize the following organizations for the financial support they provide for the ongoing research projects on which this paper is partly based. The "eGrievance system in India" is supported by the NWO-Wotro Integrated Programme: using spatial information infrastructure in urban governance networks: reducing urban deprivations in Indian cities? The "Human Sensor Web on Zanzibar" is supported by UN-Habitat and Google.org under the h2.0 Monitoring Services to Inform and Empower initiative.

\section{References}

1. Danzinger, J.N., Andersen, V.K.: The impacts of information technology on public administration: an analysis of empirical research from the 'golden age' of transformation. International Journal of Public Administration 25(5), 591-627 (2002)

2. Zouridis, S., Thaens, M.: Reflections on the Anatomy of E-Government. In: Bekkers, V.H.V. (ed.) The Information Ecology of E-Government. E-Government as Institutional and Technological Innovation in Public Administration, pp. 21-36. IOS Press, Amsterdam (2005)

3. Heeks, R.: eGovernment in Africa: Promise and Practice. Information Polity 7(2-3), $97-$ $114(2003)$

4. Saxena, K.: Towards excellence in e-governance. International Journal of Public Sector Management 18(6), 498-513 (2005)

5. Fang, Z.: E-government in digital era: concept, practice, and development. International Journal of The Computer. The Internet and Management 10(2), 1-22 (2002)

6. Criado, J., Hughes, O., et al.: e-Government and Managerialism: A Second Revolution in Public Management. In: 6th International Research Symposium on Public Management University of Edinburgh, April 8-10 (2002)

7. Verdegem, P., Verleye, G.: User-centered E-Government in practice: A comprehensive model for measuring user satisfaction. Government Information Quarterly 26(3), 487-497 (2009)

8. Ho, A.T.K.: Reinventing local governments and the e-government initiative. Public Administration Review 62, 434-444 (2002)

9. Van Deursen, A., Pieterson, W.: The Internet as a Service Channel in the Public Sector. In: Proceedings of the ICA Conference, Dresden, Germany (2006)

10. Thomas, J., Streib, G.: The new face of government: Citizen-initiated contacts in the era of e-government. Journal of Public Administration Research and Theory 13(1), 83-101 (2003)

11. Horrigan, J.: How Americans get in touch with government. Pew Internet \& American Life Project: 9 (2004)

12. Reddick, C.G.: Citizen interaction with e-government: From the streets to servers? Government Information Quarterly 22(1), 38-57 (2005)

13. McNeal, R., Hale, K., Dotterweich, L.: Citizen-Government Interaction and the Internet: Expectations and Accomplishments in Contact, Quality and Trust. Journal of Information Technology and Politics 5(2), 213-229 (2008) 
14. Chen, D., Huang, T., et al.: Citizen Participation, E-government, and Public Management: A Case of Taipei City Mayor's E-mail Box International Symposium of Digital Divide and Digital Opportunity, pp. 157-176. Yuan Ze University, Taiwan (2004),

http: / /www.infosoc.yzu.edu.tw/conference/paper/

6_02Public\%20Participation\%20E-

government $\% 20$ and $20 \mathrm{KM} \_d r a f t \_. p d f$ (accessed in June 2010)

15. OECD: The e-Government Imperative. OECD. Paris (2003)

16. Moon, M.: The evolution of e-government among municipalities: rhetoric or reality? Public Administration Review 62(4), 424-433 (2002)

17. Edmiston, K.: State and local e-government: Prospects and challenges. The American Review of Public Administration 33(1), 20-45 (2003)

18. Gil-Garcia, J., Martinez-Moyano, I.: Understanding the evolution of e-government: The influence of systems of rules on public sector dynamics. Government Information Quarterly 24(2), 266-290 (2007)

19. Kumar, V., Mukerji, B., et al.: Factors for successful e-government adoption: a conceptual framework. The Electronic Journal of e-Government 5(1), 63-76 (2007)

20. Cohen, J.: Citizen satisfaction with contacting government on the internet. Information Policy 11(1), 51-65 (2006)

21. Pieterson, W., van Dijk, J.: Channel Choice Determinants; An exploration of the factors that determine the choice of a service channel in citizen initiated contacts. In: Proceedings of the 8th Annual International Conference on Digital Government Research: Bridging Disciplines \& Domains, pp. 173-182. Digital Government Society of North America, Philadelphia (2007)

22. Sharp, E.B.: Citizen-Demand Making in the Urban Context. American Journal of Political Science 28(4), 654-670 (1984)

23. Parigi, V.K., Geeta, P., Kailasam, R.: Ushering in Transparency for Good Governance. Working Paper, Centre for Good Governance, Hyderabad (2005)

24. Ranganathan, M.: Grievance Redressal Processes in Urban Service Delivery: How Effective Are They? ADB The Governance Brief, Capacity Development and Governance Division, Regional and Sustainable Development Department, Issue 17 (2008)

25. Martínez, J.A., Pfeffer, K.H., van Dijk, T.: The capacity of e-government tools: claimed potentials, unnamed limitations. In: Proceeding of the 10th N-AERUS Conference: Challenges to Open Cities in Africa, Asia, Latin America and the Middle East: Shared Spaces within and Beyond, IHS Rotterdam, October 1-3 (2009)

26. Brewer, B.: Delivering Better Service to Citizens- Addressing Citizens Complaints Effectively: What? How? Why? In: The CAPAM 2006 Biennial Conference Rising to the Challenge: Enhancing Public Sector Capability Sydney, Australia (2006)

27. Mulgan, R.: Comparing accountability in the public and private sectors. Australian Journal of Public Administration 59(1), 87-97 (2000)

28. Brewer, B.: Citizen or customer? Complaints handling in the public sector. International Review of Administrative Sciences 73(4), 549-556 (2007)

29. UNDP: The key to increasing Transparency in e-Government deployements. Public Feedback Mechanism. APDIP e-Note 3/2005 UNDP (2005)

30. Hance, L.: (How) Are You Being Served? A Good Practice Guide on Complaints Handling in Housing Association. Housing Corporation. Tottenham (2002), http: / / www.housingcorp.gov.uk/upload/pdf/SERVED.pdf (accessed in June 2010)

31. Seneviratne, M., Cracknell, S.: Consumer Complaints in Public Sector Services. Public Administration 66(2), 181-193 (1988) 
32. Wallack, J., Nadhamuni, S.: User Innovation and eGovernance Design. In: Forthcoming in Hidden Successes: Urban Reforms in India. MIT Press, Cambridge (2007)

33. UN-Habitat: h2.0 Monitoring Services to Inform and Empower (2009), http: / / www . unhabitat.org/categories.asp?catid=635 (accessed January 22, 2010)

34. Bourn, J.: Citizen Redress: What citizens can do if things go wrong with public services. National Audit Office (NOA), London (2005)

35. Carvalho, D., Fidélis, T.: Environmental complaints in Aveiro, Portugal: actors, concerns, territorial pattern, and resolutions. Sociedade \& Natureza (Online) 21, 51-70 (2009a)

36. Carvalho, D., Fidélis, T.: The perception of environmental quality in Aveiro, Portugal: a study of complaints on environmental issues submitted to the City Council. Local Environment 14(10), 939-961 (2009b)

37. Meijer, A., Burger, N., et al.: Citizens4Citizens: Mapping Participatory Practices on the Internet. Electronic Journal of e-Government 7(1), 99-112 (2009)

38. Schumaker, P.D., Getter, R.W.: Responsiveness Bias in 51 American Communities. American Journal of Political Science 21(2), 247-281 (1977)

39. Van Dijk, J., Hacker, K.: The digital divide as a complex and dynamic phenomenon. The Information Society 19(4), 315-326 (2003)

40. Fountain, J.: Paradoxes of public sector customer service. Governance 14(1), 55-73 (2001)

41. Goodchild, M.F.: Editorial: Citizens as Voluntary Sensors: Spatial Data Infrastructure in the World of Web 2.0. International Journal of Spatial Data Infrastructures Research 2, 24 32 (2007)

42. Sheppard, S.R.J., Cizek, P.: The ethics of Google Earth: Crossing thresholds from spatial data to landscape visualisation. Journal of Environmental Management 90(6), 2102-2117 (2009)

43. Livingston, S., Aday, S.: NGOs as Intelligence Agencies: The Empowerment of Transnational Advocacy Networks and the Media by Commercial Remote Sensing. Paper Presented at the Annual Meeting of the Association of American Geographers, San Francisco, April 17-21 (2007)

44. Kingsbury, P., Jones III, J.P.: Walter Benjamin's Dionysian Adventures on Google Earth. Geoforum 40, 502-513 (2009)

45. Dodge, M., Perkins, C.: Reclaiming the Map: British Geography and Ambivalent Cartographic Practice. Environment and Planning A 40(6), 1271-1276 (2008)

46. Parks, L.: Digging into Google Earth: An analysis of "Crisis in Darfur". Geoforum 40, 535-545 (2009)

47. Craglia, M., et al.: Next-Generation Digital Earth. International Journal of Spatial Data Infrastructures Research 3, 146-167 (2008)

48. Harvey, F.: Just another private - public partnership? Possible constraints on scientific information in virtual map browsers. Environment and Planning B: Planning and Design 2007 34, 761-764 (2007)

49. Perkins, C., Dodge, M.: Satellite Imagery and the Spectacle of Secret Spaces. Geoforum 40(4), 546-560 (2009)

50. Poelmans, M., Van der Linde, X.: The e-Citizen Charter as a Tool for Measuring Citizen Satisfaction on the Basis of Life Events. In: Cunningham, P., Cunningham, M. (eds.) eChallenges e-2009 Conference Proceedings, IIMC International Information Management Corporation (2009)

51. Thorp, J., Just Landed: Processing, Twitter, MetaCarta \& Hidden Data (2009), http: / /blog.blprnt.com/blog/blprnt/just-landed-processingtwitter-metacarta-hidden-data (accessed on January 22, 2010) 
52. McNeil Jr., D.G.: Predicting Flu With the Aid of (George) Washington. Article Published in the New York Times, May 4, page A1 (2009)

53. Kalyan Dombivli Municipal Corporation: City Development Plan for Kalyan Dombivli Municipal Corporation. Kalyan Dombivli Municipal Corporation, Kalyan Dombivli (2006)

54. ABM: Project KDMC (2009), http: / / www . abmindia . com/kdmc.html

55. Dolare, S.: MSEDC upsets Old Kalyan consumers Dombivali Kalyan Plus, Saturday (September 29, 2007)

56. Sharma, S.: KDMC's e-governance misleading, complains Kalyan resident Dombivali Kalyan Plus, Saturday (June 7, 2008)

57. Jürrens, E.H., Bröring, A., et al.: A Human Sensor Web for Water Availability Monitoring. In: OneSpace 2009 - 2nd International Workshop on Blending Physical and Digital Spaces on the Internet, Berlin, Germany (2009)

58. Google Earth Outreach: Trading bows and arrows for laptops (2008), http: / / www . youtube. com/watch?v=tNp9j103CKk (accessed on January 22, 2010)

59. Howard, P.N., Mazaheri, N.: Telecommunications Reform, Internet Use and Mobile Phone Adoption in the Developing World. World Development 37(7), 1159-1169 (2009)

60. Sung, C.Y.: Understanding of data quality in human sensor web. University of Twente, Enschede (2010)

61. Wegener, M., Masser, I.: Brave new GIS worlds. In: Masser, I., Campbell, H., Craglia, M. (eds.) GIS Diffusion: The Adoption and Use of Geographical Information Systems in Local Government in Europe. Taylor \& Francis, London (1996)

62. Albrechtslund, A.: In the Eyes of the Beholder: Introducing participation and ethics to surveillance. Aalborg University, Aalborg (2008)

63. Lane, N.D., Eisenman, S.B., Miluzzo, E., Musolesi, M., Campbell, A.T.: Urban Sensing: Opportunistic or Participatory? In: ACM SenSys 2007, Sydney, Australia (2007)

64. Tomtom: How TomTom's HD Traffic ${ }^{\mathrm{TM}}$ and IQ Routes ${ }^{\mathrm{TM}}$ data provides the very best routing; Travel Time Measurements using GSM and GPS Probe Data. Whitepaper (2009), http://www.tomtom.com/lib/doc/download/HDT_White_Paper.pdf (accessed on January 22, 2010)

65. Coleman, D.J., Georgiadou, Y., Labonte, J.: Volunteered geographic information: the nature and motivation of producers. International Journal of Spatial Data Infrastructures Research 4, 332-358 (2009)

66. Mansell, R.: The information society and ICT policy; A critique of the mainstream vision and an alternative research framework. Journal of Information, Communication \& Ethics in Society 8(1), 22-41 (2010)

67. Ginsberg, J., Mohebbi, M.H., Patel, R.S., Brammer, L., Smolinski, M.S., Brilliant, L.: Detecting influenza epidemics using search engine query data. Nature 457, 1012-1014 (2009)

68. Avgerou, C.: Information Systems and Global Diversity. Oxford University Press, Oxford (2002)

69. Bruns, A.: Blogs, Wikipedia, Second Life, and Beyond: From Production to Produsage. In: Digital Formations, vol. 45. Peter Lang, New York (2008)

70. Hoogenboom, M., Ossewaarde, R.: From Iron Cage to Pigeon House: The Birth of Reflexive Authority. Organization Studies 26(4), 601-619 (2005)

71. Beck, U.: Risk Society, Towards a New Modernity. Sage Publications, London (1992)

72. H2.0 - Human Sensor Web - Client (2010), http://geoserver.itc.nl/zanzibar/ (accessed on May 15, 2010) 